\title{
Metastatic Ovarian Small Cell Carcinoma, Hypercalcemic Type
}

National Cancer Institute

\section{Source}

National Cancer Institute. Metastatic Ovarian Small Cell Carcinoma, Hypercalcemic Type. NCl Thesaurus. Code C27391.

A primary small cell carcinoma of the ovary that is associated with hypercalcemia and has metastasized to other anatomic sites. 